\title{
Enhancing transparency through company law reform in China
}

\author{
DR JINGCHEN ZHAO*
}

University of Leeds

\begin{abstract}
$\underline{\text { Abstract }}$
A growing awareness of corporate social responsibility (CSR) is always reflected by an increase in the number of CSR or sustainability reports published, as well as in the provision of CSR-related information. The growing importance of socially responsible investment and of the media are converging, and an increasing awareness of companies' social, etbical and environmental performance calls for greater transparency in reporting. Corporate disclosure is one of the most common means of ensuring adherence to corporate governance principles such as fairness and transparency. This issue is particularly important for China, where guanxi and government control are regarded as key elements for business transactions. This article sets out to explore the emerging practice of CSR reporting in China to examine whether current practice is motivated by the purpose of discharging accountability to relevant stakeholders, and also whether it is helpful to transplant the UK's 'strategic report' system to China. It is salient to discuss why the CSR reporting system is important to China in order to promote CSR and a harmonious society, and how to enforce the scheme by mandatory regulations and voluntary guidelines. If a CSR reporting system is established, there is likely to be resistance to major regulatory changes. It would be desirable to maintain a balance between efficient disclosure and increased burdens for companies in order to acbieve the ultimate purpose of boosting the competitive advantages of companies through increased transparency via corporate disclosure.
\end{abstract}

\section{Introduction}

$\mathrm{O}$ ver the last three decades China has achieved unprecedented economic growth as 'a champion of a state-led growth model'. ${ }^{1}$ China represents an important and contemporary environment for research, practice and legislation for CSR by virtue of the distinctive roles of its government and regulation, and the globalisation of the Chinese economy. Investigation of Chinese companies' engagement with CSR, in comparison with the overall discussion and literature related to CSR in general, is rather limited, and the idea of CSR in China is comparatively new to companies and related academic research. China is infamous for corporate scandals such as sweatshops, environmental pollution problems,

\footnotetext{
* Associate Professor in Law, Centre of Business Law and Practice, School of Law, University of Leeds. The author can be contact via j.zhao@leeds.ac.uk. I thank Professor Sally Wheeler, the editor, for her encouragement and support.

1 Benjamin van Rooij, 'Inaugural Lecture: The People's Regulation: Citizens and Implementation of Law in China', 2011, University of Amsterdam.
} 
poor working conditions and, especially recently, for food safety and product safety issues, with the more than 300,000 victims from the SanLu baby milk scandal as an example. Enforcement approaches that have been the subject of international academic discussion include: CSR-related legislation within Chinese company law (CCL) ${ }^{2}$ the Code of Corporate Governance for Listed Companies in China; ${ }^{3}$ administrative measures on information disclosure of listed companies and the Listing Rules of the Stock Exchange 2010; administrative organisations; ${ }^{4}$ and other laws such as the Chinese Employment Contract Law 2008. ${ }^{5}$ Among these approaches to enforcing CSR measures within corporate strategies, directors' duties towards stakeholders and mandatory information disclosure have been regarded as two direct measures in corporate law which can act to embed the legislative approach on CSR into corporate behaviours and decisions through progressive corporate law. This article will focus on information disclosure, especially within a legal context, to explain the uniqueness, characteristics, content and purpose of the CSR information disclosure system in China. ${ }^{6}$

As one of the most common means of achieving transparency, corporate disclosure is first emphasised by using the analogy that 'sunshine is said to be the best of disinfectants; electronic light the most efficient policeman'. ${ }^{7}$ It is regarded as a corporate governance principle that stakeholders should have access to relevant, sufficient and reliable information on a timely and regular basis. ${ }^{8}$ Disclosure assists in making the securities market more transparent, and it is effective in maintaining the confidence of investors who trade on the basis of securities information. Securities markets have always regarded information disclosure as a fundamental issue. ${ }^{9}$ Furthermore, corporate disclosure also has the effect of raising corporate governance standards with the purpose of building business aims and principles, since it enhances accountability. ${ }^{10}$ The Chinese Corporate Governance Code 2002, in line with the Organization for Economic Co-operation and Development (OECD) Principles of Corporate Governance, included information disclosure and transparency' as a chapter in itself and urged listed companies to 'truthfully, accurately, completely and in a timely manner disclose information as required by laws, regulations and the company's articles of association'. ${ }^{11}$ However, absent a corporate governance code after 2002, there has been little up-to-date discussion on mandatory information disclosure of CSR issues, either in China or generally. ${ }^{12}$ As a result, it is important to study CSR disclosure within mandatory aspects in CCL to fill the literature gap.

2 See Article 5 CCL 2006.

3 See ss 81-8 Code of Corporate Governance for Listed Companies in China.

4 Environmental Protection Agency, the Equal Employment Opportunity Commission, the Occupational Safety and Health Administration and the Consumer Product Safety Commission.

5 Ss 12, 14 and 15 Chinese Employment Contract Law 2008.

6 For discussions on uniqueness of corporate governance and CSR, see H Chen and X Wang, 'Corporate Social Responsibility and Corporate Financial Performance in China: An Empirical Research from Chinese Firms' (2011) 11 Corporate Governance 361; J Zhao, 'Promoting Stakeholders' Interests in the Unique Chinese Corporate Governance Model: More Socially Responsible Corporations?' (2010) International Company and Commercial Law Review 373.

7 L D Brandeis, Other People's Money and How the Bankers Use It (National Home Library Foundation 1933) 62.

8 Principle IV.D, Chinese Securities Regulatory Committee, OECD-China Policy Dialogue on Corporate Governance: Corporate Governance of Listed Companies in China; Self-Assessment by the China Chinese Securities Regulatory Committee (OECD 2011).

$9 \mathrm{~J} \mathrm{Fu}$, Corporate Disclosure and Corporate Governance in China (Kluwer Law International 2010) 23-4.

10 A Cadbury and I M Millstein, 'The New Agenda for ICGN, Discussion Paper No 1' for the International Corporate Governance Network 10th Anniversary Conference, 13 July 2005, London <www.icgn.org/403>.

11 S 87 Code of Corporate Governance for Listed Companies in China.

12 D G Barakas and A M Brown, 'Corporate Social Reporting and Board Representation: Evidence from Kenyan Banking Sector' (2008) 12 Journal of Management and Governance 309. 
Countries with emerging markets, such as China, always suffer more with social and environmental problems faced by multinational and domestic companies. These problems include workplace issues, which cover an expanding range of topics (such as labour standards), marketplace issues (most notable in emerging markets is the integrity of product manufacturing and quality) and environmental issues (to promote the sustainability of the companies). The growing importance of socially responsible investment and of the media are converging, and an increasing awareness of companies' social, ethical and environmental performance calls for greater transparency in reporting. ${ }^{13}$ Transparency has been regarded as a critical component of corporate governance regimes, and openness can be achieved through clear disclosure and reporting and through engagement and dialogue among directors, shareholders and stakeholders. CSR-related information disclosure makes it possible for profitable companies to show that their business operations and decisions have been performed within the norms of society, and demonstrate that they are fully aware of the costs of breaching society's expectations. ${ }^{14}$ Legislation in mandating disclosure of certain pieces of CSR-related information in different corporate disclosure documents such as the periodic disclosure documents, the financial statement and the accompanying notes, the annual report or the corporate governance report, and also certain continuous disclosure documents - will help multi-stakeholder governance and corporate suitability. ${ }^{15}$

The paper will begin with a discussion of the CCL system in order to better understand how CSR fits into the current international regime. Special attention will be paid to information disclosure requirements with a discussion of the existing rules and the inadequacy of mandatory requirements for CSR-related information disclosure within CCL. Thereafter, the question arises of how to establish an effective and efficient CSR information disclosure system in China, incorporating both mandatory and voluntary elements. The mandatory origins will be discussed with broader corporate objective requirements within Chinese Company Law 2006. This article then sets out to explore the emerging practice of CSR reporting in China to examine whether current practice is motivated for the purpose of discharging accountability to relevant stakeholders and whether it is helpful to transplant the international code and the strategic report requirement embedded in the UK Companies Act 2006. Two-way communication within a reporting system with strong government interference will be suggested at the end of the article as a way to make information disclosure more enforceable and efficient in China.

\section{Regulation of CSR and transparency requirements under CCL}

A sound legal system with efficient enforcement measures is necessary for CSR enforcement in order to protect the interests of various non-shareholder stakeholders. ${ }^{16}$ Chinese law does provide compulsory requirements for CSR regarding fundamental and instrumental CSR issues, with a wide range of standards in place concerning environmental

13 N Dando T Swift, 'Transparency and Assurance: Minding the Credibility Gap' (2003) 44 Journal of Business Ethics 195, 195-6.

14 K Bewley and Y Li, 'Disclosure of Environmental Information by Canadian Manufacturing Companies: A Voluntary Disclosure Perspective' (2000) 1 Advances in Environmental Accounting and Management 201, 203.

15 See D G Szabo, 'Disclosure of Material CSR Information in the Periodic Reports - Comparison of the Mandatory CSR Disclosure Systems for Listed Companies in the EU and the US' Nordic and European Company Law Working Paper 10-20 (2011) <http://papers.ssrn.com/sol3/papers.cfm?abstract_id $=1927232>$.

16 OECD, 'Corporate Governance of Listed Companies in China: Self-Assessment by the China Securities Regulatory Commission' (OECD 2011) 95. 
protection, product quality safety and employees' interests. ${ }^{17}$ Mechanisms that protect the interests of various stakeholders are defined in departmental laws including Chinese Company Law 2006, the Law on Commercial Banks 1995 (amended 27 December 2003), the Law of Employment Contract of China 2008, the Securities Law 2006 and the Enterprise Bankruptcy Law 2007.18 At the company law level, the old CCL launched in 1994 did not explicitly make reference to CSR.

Legislators of the new CCL incorporated a CSR element directly into Article 5 of CCL 2006, stating that:

a company must, when engaging in business activities, abide by the laws and administrative regulations, observe social morals and business ethics, be in integrity and good faith, accept regulation of the government and the public, and undertake social responsibilities.

This is a broad legislative attempt to clarify that corporate objectives, apart from making profits for shareholders, also include social and environmental aspects. It is implied that apart from the interests of shareholders, interests of employees, creditors and other stakeholders should also be considered for companies' public social interests. Therefore, when company directors and supervisors pursue the interests of their shareholders, they also have to be socially responsible to internal and external stakeholders. Moreover, contemporary modern terms such as 'business ethics' and 'social responsibilities' were introduced into the general provisions to make them consistent with the goal of sustainability within the wider political policy of a harmonious society. ${ }^{19}$ In addition to Article 5, which requires that directors go beyond economic and legal responsibility to encompass social and philanthropic responsibility, the rights of employees, as primary internal stakeholders, were also emphasised in the new CCL 2006, ${ }^{20}$ which may help to illustrate the approach underlying Article 5. Moreover, in terms of the legislative tenets, Article 1 of CCL 2006 makes it clear that this legislation was enacted in order to:

standardise the organisation and activities of companies, to protect the legitimate rights and interests of companies, shareholders and creditors, to maintain socioeconomic order and to promote the development of the socialist market economy. 21

The interests of creditors, as primary external stakeholders, were explicitly adopted, along with the interests of shareholders and the company itself.

In spite of the country's impressive economic growth, it is common knowledge that China has weak legal institutions and poor protection of property rights, including intellectual property, and its capital market is characterised by prevalent earnings

17 OECD (n 16).

18 See Articles 1 and 5 CCL 2006; Articles 6, 29-33 Law on Commercial Banks 1995; Articles 2, 5, 17,2151 and 87 Law of Employment Contract of China; and Articles 1, 5 and 6 Enterprise Bankruptcy Law 2007.

19 For discussions on linkage between the harmonious society and CSR, see K H Darigan and J E Post, "Corporate Citizenship in China: CSR Challenges in the "Harmonious Society" (2009) 35 Journal of Corporate Citizenship 39; D Karlsson, Corporate Social Responsibility: A Tool for Creating a Harmonious Society in China (European Institute for Asian Studies 2011); G See, 'Harmonious Society and Chinese CSR: Is There Really a Link?' (2008) 89 Journal of Business Ethics 1.

20 Articles 17, 18, 51 and 117 CCL 2006.

21 Article 1 CCL 2006. 
manipulation and high stock return synchronicity. ${ }^{22}$ Enforcement normally refers to the implementation of national legislation together with international law that China is bound by, and international law and treaty obligations are thought to prevail if there is a conflict between domestic law and an obligation from an international treaty which binds China by law. ${ }^{23}$ Although it is positive that the government is making initial efforts to realise the importance of CSR and make it legitimate for directors to consider their responsibility beyond shareholder value maximisation, it is still important to identify the approaches by which the Chinese government may enforce these rules.

The proper implementation and enforcement of CSR-related laws seems to be the future of CSR, with government interference, supervision and promotion needed in order to turn CSR-related laws in CCL into law-in-action rather than law-in-books. Strict information disclosure requirements on listed companies are an important way of enforcing CSR-related legal requirements and ensuring that stakeholders are informed of socially responsible corporate actions and decisions. However, the statistics do not reflect a very positive trend.

In 2008, it was estimated that among 1625 listed companies in China, ${ }^{24}$ only 162 of the companies listed on the Shenzhen Stock Exchange and 290 on the Shanghai Stock Exchange disclosed their reports. ${ }^{25}$ CSR reports in China are not typically audited and the quality of the CSR disclosure tends to be poor, as illustrated by a report from SynTao Sustainability Solution, a CSR consulting firm. ${ }^{26}$ It is reported that only 5 per cent of the 535 CSR reports surveyed in 2009 were independently audited, and over 50 per cent of the reports contained no more than 10 pages. ${ }^{27}$ However, the situation has improved since then as indicated from KPMG statistics in 2011 regarding the largest companies in China. ${ }^{28}$ China was new to this survey in 2011 and was in a full-out sprint to catch up with the traditional leaders in the field, with almost 60 per cent of China's largest companies reporting, according to corporate responsibility metrics. Again, another study by SynTao also showed improvements in CSR reporting based on data collected in 2012-2013. ${ }^{29}$ There was a total of 1705 CSR reports released in 2012. The overall number of reports increased by over 70 per cent compared with the previous year. ${ }^{30}$ This was confirmed by the KPMG

22 See F Allen, R Chakrabarti, S De, J Qian and M Qian, 'Law, Institutions and Finance in China and India' in B Eichengreen, P Gupta and R Kumar (eds), Emerging Giants: China and India in the World Economy (OUP 2010) 125. See also R Morck, B Yeung and W Yu, 'The Information Content of Stock Markets: Why Do Emerging Markets Have Synchronous Stock Price Movement?' (2000) 58 Journal of Financial Economics 215.

23 K Buhmann, 'Corporate Social Responsibility in China: Current Issues and their Relevance for Implementation of Law' (2005) 22 Copenhagen Journal of Asian Studies 62, 78; J Chen, Y Li and J M Otto, Implementation of Law in the People's Republic of China (Kluwer 2002).

24 Data from China Securities Regulatory Commission <www.csrc.gov.cn/pub/zjhpublic/G00306204/ zqscyb/200901/t20090120_108744.htm>.

25 OECD, 'Corporate Governance of Listed Companies in China: Self-Assessment by the China Securities Regulatory Commission' (OECD 2011) 102.

26 All documents can be downloaded via <www.syntao.com/Resources/SustainabilityReport_Show_CN.asp>.

27 SynTao China Sustainability Reporting Centre, A Journey to Discover Values: A Study of Sustainability Reports in China (Syn'Tao 2009).

28 KPMG, KPMG International Survey of Corporate Responsibility Reporting 2011 (KPMG 2011).

29 SynTao China Sustainability Reporting Centre, A Journey to Discover Values: A Study of Corporate Social Responsibility Reports in China (Syn'Tao 2012-2013).

30 Ibid 2. 
statistics in 2013 that 75 per cent of companies report on their CSR. ${ }^{31}$ However, the percentage of reports that were independently audited dropped to 3 per cent in 2012. Nevertheless, it is predicted that China will enjoy a widespread reporting system in the future. $^{32}$ This improvement does make mandatory information disclosure for CSR issues possible and necessary. Mandatory information disclosure for listed companies on social and environmental issues can be accommodated as one of the most effective ways to facilitate CSR in action and change the current state of corporate reporting on CSR issues.

\section{Normative justification for regulating CSR-related information disclosure}

CSR-related reporting, while not mandatory in most countries, has been accommodated and adopted in many corporations around the world. There are a variety of competing global standards for non-financial reporting, such as the Global Reporting Initiative (GRI) 33 and the UN Global Compact. ${ }^{34}$ Although it can be initially traced back to the 1970 s, ${ }^{35}$ CSR reporting re-emerged from the mid-1990s onwards in research and practice in the fields of corporate governance, accounting and auditing. The concepts of CSR reporting or CSRrelated information disclosure reporting have also been referred to as sustainability reporting, social responsibility accounting, ${ }^{36}$ social accounting ${ }^{37}$ and corporate social disclosure, ${ }^{38}$ and they have been popularised using the acronym SEAAR (social and ethical accounting, auditing and reporting). ${ }^{39}$ According to the KPMG International Survey of Corporate Responsibility Reporting 2013, the most popular terms used are sustainability report (43 per cent), CSR report ( 25 per cent), corporate responsibility report (14 per cent) and sustainable development report (6 per cent).

Corporate responsibility reporting has established its position as the de facto law for business, delivering a compelling insight into the expectations that companies face. ${ }^{40}$ Based on the KPMG International Survey of Corporate Responsibility Reporting 2013 for the G250 companies, drawn from the Fortune Global 500 List and representing more than a dozen industry sectors, there has been an upward trend in CSR reporting. It is said that CSR reporting sees exceptional growth in emerging economies. ${ }^{41}$ The corporate report grew by 53 per cent in India, 46 per cent in Chile and 16 per cent in China. An expanded social disclosure generally starts with information on the products a company produces, extending to the company's law compliance structure, its domestic and global labour practices, its supplier/vendor standards and global environmental effects. ${ }^{42}$ The attention of legislators focuses on making CSR mandatory, embedded in corporate strategies within the companies, and this includes mandatory information disclosure in company law through reviews or

31 KPMG, KPMG International Survey of Corporate Responsibility Reporting 2013 (KPMG 2013) 13.

32 KPMG (n 28) 10.

33 For more information, see the official website <www.globalreporting.org/Pages/default.aspx $>$.

34 For more information, see the official website <www.unglobalcompact.org $>$.

35 A R Belal, Corporate Social Responsibility Reporting in Developing Countries: The Case of Bangladesh (Ashgate 2008) 6.

36 M R Mathews, 'A Suggested Classification for Social Accounting Research' (1984) 3 Journal of Accounting and Public Policy 199.

37 R Gray, 'Current Developments and Trends in Social and Environmental Auditing, Reporting and Attestation: A Review and Comment' (2000) 4 International Journal of Auditing 247.

38 A R Belal, 'A Study of Corporate Social Disclosures in Bangladesh' (2001) 16 Managerial Auditing Journal 274.

39 C Gonella, A Piling and S Zadek, 'Making Values Count: Contemporary Experience in Social and Ethical Accounting' (ACCA 1998).

40 KPMG (n 28) 2.

41 KPMG (n 31) 10.

42 C A Williams, 'The Securities and Exchange Commission and Corporate Social Transparency' (1999) 112 Harvard Law Review 1197, 1201-2. 
reports which should be available to shareholders, stakeholders and even the public at large. ${ }^{43}$ Meanwhile, public companies, in response to increasing public concerns about corporate social performance and social responsiveness, are becoming increasingly open about the social and environmental impacts of their business activities, especially with the growing number of multinational corporations and their acceptance and awareness of global CSR reporting standards. ${ }^{44}$

CSR reporting is increasingly regarded as a result of the debate over corporate governance globally with the purpose of promoting transparency and accountability of corporations. It is concluded that increased transparency in corporate disclosure, especially in the aftermath of the financial crisis, will boost the competitive advantages of companies which aim for it. ${ }^{45}$ Our results show that the number of CSR reports significantly increased after the crisis. It was found through empirical research that the economic crisis has affected the strategy on CSR reporting. Rather than reducing the number of reports published, in fact, the crisis has actually increased the trend for reporting. ${ }^{46}$ Fitting into the enlightened requirements of corporate objectives, two legislative attempts always go hand in hand in corporate law to achieve these goals for the long-term interests of corporations, namely directors' duties and mandatory information disclosure for public companies. ${ }^{47}$ Explicit recognition of the interests of stakeholders should be made a legal requirement - or at least it should be legitimately approved or explicitly permitted under company law through provisions related to directors' duties, shareholders' rights, stakeholders' rights (the rights of creditors and employees are most often discussed), and information disclosure requirements. ${ }^{48}$ While directors are given legitimacy to consider the interests of stakeholders, it is logical to understand the system as the external reporting of ethical, social and environmental aspects of a corporation, while corporations try to achieve information disclosure aspects beyond the traditional boundaries by providing a financial account to the shareholders under the assumption that companies have and will carry out responsibilities beyond making profits.

In recent years, with the more transparent media disclosure, we have witnessed many corporate scandals in China, while the whole of society, especially manufacturers, has to bear the social cost as a result of these scandals. As well as getting attention from

43 Szabo (n 15) 1-2.

44 S Chen and P Bouvain, 'Is Corporate Responsibility Converging? A Comparison of Corporate Responsibility Reporting in the USA, UK, Australia and Germany' (2009) 87 Journal of Business Ethics 299, 300.

45 O Aiyegbayo and C Villiers, 'The Enhanced Business Review: Has It Made Corporate Governance More Effective?' (2011) Journal of Business Law 699, 720.

46 A Garcia-Benau, L Sierra-Garcia and A Zorio, 'Financial Crisis Impact on Sustainability Reporting' (2013) 51 Management Decision 1528.

47 A good example would be ss 172 (1) and 414 UK Companies Act 2006, and ss 74 and 66(2)(c) Company Law of the Republic of Indonesia 2007.

48 For example, see D McBarnet, A Voiculescu and T Campbell (eds), The New Corporate Accountability: Corporate Social Responsibility and the Law (CUP 2007); K Buhmann, 'Corporate Social Responsibility: What Role for Law? Some Aspects of Law and CSR' (2006) Corporate Governance 188; C Villiers, 'Corporate Law, Corporate Power and Corporate Social Responsibility' in N Boeger, R Murray and C Villiers (eds), Perspectives on Corporate Social Responsibility (Edward Elgar 2010); J Zhao, 'Promoting More Socially Responsible Corporations through UK Company Law after the 2008 Financial Crisis: Turning of the Crisis Compass' (2011) 22 International Company and Commercial Law Review 275; P Puri, 'The Future of Stakeholder Interests in Corporate Governance' (2010) 48 Canadian Business Law Journal 427; J E Kerr, 'Sustainability Meets Profitability: The Convenient Truth of How the Business Judgement Rule Protects a Board's Decision to Engage in Social Entrepreneurship' (2007) 29 Cardozo Law Review 623; R I Patel, 'Facilitating Stakeholder-Interest Maximization: Accommodating Beneficial Corporations in the Model Business Corporation Act' (2010) 23 St Thomas Law Review 135; A Mickels, 'Beyond Corporate Social Responsibility: Reconciling the Ideals of a For-Benefit Corporate with Director Fiduciary Duties in the US and Europe' (2009) 32 Hastings International and Comparative Law Review 271. 
government, media, business and society, corporate social reporting is also becoming an increasing concern for academics from disciplines such as law, accounting, corporate governance and strategic management. ${ }^{49}$ The legal responses to CSR and inadequate protection for various stakeholders have to be understood with reference to China's unique corporate governance and legal system, with its singular legislative, litigation and enforcement procedures. As non-financial CSR reporting is usually prepared on a voluntary basis, this begs the question of whether it is useful and possible for directors of listed companies to exploit annual reports as the most direct and enforceable way to legitimise CSR conduct as a complementary practice to promote the reputation and trustworthiness of Chinese companies and products that are made in China. This seems a rational and efficient way for China - a country with long-term coexistence of administrative corporate governance and economic corporate governance in which government could intervene with the business decision-making process by administrative means - to enforce CSR, allowing less unpoliced discretion for company decision-makers. Shareholders and other stakeholders in China who shoulder greater political or social risks will find the disclosed information useful, informing them what the company has done to avoid negative CSRrelated shocks and scandals. It also fits within the business case for CSR to enhance the corporation's legitimacy and reputation through disclosure of information about CSR in order to illustrate that its operations are consistent with social norms and expectations. ${ }^{50}$

\section{The current regulatory framework for CSR reporting in China: problems, challenges and opportunities}

Looking at the main legislation regulating public companies, the mandatory requirements on CSR information disclosure are unsatisfactory. According to CCL $2006^{51}$ and the Chinese Securities Law 2006, 52 listed companies are required to disclose regular reports, in the form of a financial report, an accounting report, annual reports, half-year reports and quarterly reports, on a timely basis. However, the content of these mandatory reports has always focused on the financial aspects of the company. For example, a company is required by CCL 2006 to formulate a financial report and have it checked by an accounting firm according to the relevant laws, administrative regulations and the provisions of the treasury department of the State Council. ${ }^{53}$ According to the Securities Law 2006, listed companies are required to submit interim reports which contain information including financial accounting reports, business reports, major lawsuit(s), and changes in shares and corporate bonds. ${ }^{54}$ According to CCL 2006, annual reports are also required to disclose information including: company profile; financial accounting reports; business reports; profiles of

49 See A A Ullmann, 'Data in Search of a Theory: A Critical Examination of the Relationship among Social Performance, Social Disclosure, and Economic Performance of US Firms' (1985) 10 Academy of Management Review 540; R Gray, R Kouhy and S Lavers, 'Corporate Social and Environmental Reporting: A Review of the Literature and a Longitudinal Study of UK Disclosure' (1995) 8 Accounting, Auditing and Accountability Journal 47; D M Patten, 'Media Exposure, Public Policy Pressure, and Environmental Disclosure: An Examination of the Impact of Tri Data Availability' (2002) 26 Accounting Forum 152; W G Blacconiere and W D Northcut, 'Environmental Information and Market Reactions to Environmental Legislation' (1997) 12 Journal of Accounting, Auditing and Finance 149.

50 A B Carroll and K M Shabana, 'The Business Case for Corporate Social Responsibility: A Review of Concept, Research and Practice' (2010) International Journal of Management Review 86, 99-100.

51 Articles 33, 97, 145, 164 and 165 CCL 2006.

52 Articles 14, 52, 65, 66 and 68 Chinese Securities Law 2006. Of course, there are also related requirements in Administrative Measures on Information Disclosure by Listed Companies and the Measures for the Administration of Material Asset Reorganisation by Listed Companies at non-government legislation level.

53 Article 164 CCL 2006.

54 Article 65 Chinese Securities Law 2006. 
directors, supervisors and senior management personnel and their shareholdings; existing shares and corporate bonds; and the actual controlling party of the company. ${ }^{55}$ These mandatory information disclosure requirements have focused exclusively on the financial aspects of companies while information about non-financial issues, such as environmental matters, employees' interests, human rights issues, and social and community issues, have been ignored, although these have been accommodated in legislation in other jurisdictions. ${ }^{56}$

Despite the lack of mandatory requirements for reporting of social and environmental issues in CCL 2006 or Securities Law 2006, CSR disclosure initiatives were launched by government sectors, government agencies and stock exchanges to enhance the effectiveness of Article 5 in the new CCL 2006 by accommodating CSR into corporate objective stipulation. This is regarded as a result of identifying sustainable development as a priority national strategy and the Chinese government has made great efforts to encourage Chinese enterprises to become more socially and environmentally responsible to their stakeholders. At the national level, the State-owned Assets Supervision and Administration Commission (SASAC) released a directive entitled 'Guidelines to the State-Owned Enterprises Directly under the Central Government on Fulfilling Corporate Social Responsibilities' in January 2008, encouraging fulfilling CSR 'so as to realise coordinated and sustainable development of enterprises, society and environment in all respects'. ${ }^{57}$ In order to make the CSR information mechanism effective and efficient, regular communication and dialogue are also explicitly required of the state-owned enterprises (SOEs) to enable their stakeholders to provide feedback and give their responses speedily and 'all the information and feedback should be publicised to receive supervision from stakeholders and society'. ${ }^{58}$ Despite the fact that this requirement for non-financial information disclosure is only limited to SOEs in China, it is a valuable legislative process for introducing a CSR information-releasing system and a CSR communication/dialogue mechanism. These two systems can be regarded as two fundamental bases to help the mandatory information disclosure work efficiently with the regulation of corporate law. They ensure that the corporations are disclosing appropriate and accurate information for shareholders and stakeholders on their social and environmental decisions and corporate actions.

At the level of stock exchanges, it is worth mentioning that both the Shenzhen Stock Exchange and the Shanghai Stock Exchange have also taken the initiative in promoting social and environmental disclosure, releasing the 'Shenzhen Stock Exchange Social Responsibility Instruction to Listed Companies' in 2006, the 'Guidelines on Environmental Information Disclosure for Listed Companies of the Shanghai Stock Exchange' in 2008, and the 'Notice on Strengthening Listed Companies' Assumption of Social Responsibility' in 2008. These guides were introduced with the purpose of 'achieving scientific development, building a harmonised society, advancing towards economic and social sustainable development and promoting corporate social responsibility'.59 As for the information disclosure requirement, stakeholder groups, including creditors, suppliers and customers, were explicitly mentioned in the Shenzhen Stock Exchange 'Social Responsibility Instruction to Listed Companies' when discussing information disclosure requirements that were not solely for shareholders. It is stipulated that companies shall

55 Articles 65-8 Chinese Securities Law 2006.

56 For example, the UK Companies Act 2006 and Indian Companies Act 2013.

57 See State-owned Assets Supervision and Administration Commission, 'Guidelines to the State-Owned Enterprises Directly under the Central Government on Fulfilling Corporate Social Responsibilities’, preface.

58 Ibid s 18.

59 Article 1 'Shenzhen Stock Exchange Social Responsibility Instruction to Listed Companies 2006'. 
'inform the creditors in a timely manner of the material information relating to the creditors' rights and interests' 60 and 'keep confidential the personal information of their suppliers and customers and, without authorization or permission, may not use or sell such information for profit'. 61 According to the 'Notice on Strengthening Listed Companies' Assumption of Social Responsibility of Shanghai Stock Exchange in 2008, all listed companies are encouraged to enhance their own CSR awareness by developing a strategic plan on CSR-related issues for their corporate operations and they may disclose the goals and achievements of their CSR activities and annual social responsibility reports through announcements posted temporarily on the Shanghai Stock Exchange website. ${ }^{62}$

Regulatory attempts have also come from a provincial level, such as the 'Guidelines for Corporate Environmental Reports of Shandong Province 2008', 'Guidelines for CSR Reports for Industrial Enterprises of Anhui Province 2013', and 'Guidelines for CSR Reports for Industrial Enterprises of Shanxi Province 2013'. These guidelines will normally have an impact on companies registered in a province, although they will have limited influence on listed companies. Taking the guidelines for Shanxi Province as an example, it is stipulated, when discussing content of a CSR report, that the CSR information needs to be true and accurate, and that product promotion is not exaggerated, false, or misleading to the public. ${ }^{63}$

From the discussions above, it can be seen that Chinese government agencies, stock exchanges and local governments have introduced various CSR rules and norms about information disclosure. These regulations are issued with the consistent positive purpose of promoting CSR practice in China. However, different polices sometimes also have negative impact by requiring companies to prepare a lot of repetitive work in terms of CSR reports, involving unnecessary burdens and costs. The disadvantages of scattered and dispersed information discourse may be improved by setting minimum mandatory CSR reporting requirements for listed companies in CCL in order to unify basic standards to achieve multistakeholder engagement and corporate accountability.

Despite the problems of possibilities of repetitiveness and the time and moneyconsuming processes, it is not the intention of the author to criticise this hybrid regulatory framework, which works in the short term in China (on the contrary, the author actually thinks that it contains the seeds of a unique Chinese case, which will be discussed in section 6). However, the incomplete and unbalanced regulatory documents from various sources may also be confusing and misleading. For example, one company listed in Shenzhen Stock Exchange could be subject to guidelines from Guangdong Province, the Shenzhen Stock Exchange and SASAC all at the same time, and from the Ministry of Environmental Protection regarding environmental issues. The process of producing various documentations is inefficient, complicated and expensive. It also has a negative effect on promoting China as an attractive place for international investors. Therefore, considering that the Chinese government and stock exchanges and other regulators have launched an unprecedented number of CSR initiatives in recent years, rather than introducing additional regulations for CSR information disclosure, it is more sensible to consider the issue of how to make these hybrid regulatory regimes from sources at different levels work in a more effective and structured manner. A mandatory information disclosure

60 Article 12 Shenzhen Stock Exchange Social Responsibility Instruction to Listed Companies 2006.

61 Ibid Article 25.

62 S 3 Notice on Strengthening Listed Companies' Assumption of Social Responsibility of Shanghai Stock Exchange 2008 .

63 S 5.3 Guidelines for CSR Reports for Industrial Enterprises of Shanxi Province 2013. 
requirement on social, environmental and human rights issues for public companies in CCL will set the minimum standard for CSR information disclosure. This requirement on listed companies will partly achieve the legislative intention for corporate objectives embedded in Article 5 of CCL 2006. This will definitely help promote the long-term interests of companies through the harmonious society political policy. The proposed legislation may also reduce information asymmetry if the reports are informative about firms' social and political risk, and therefore help investors to assess a firm's future prospects by helping them assess a firm's political or social risks and increasing analysts' coverage. ${ }^{64}$ The minimum requirement, together with regulations from other sources, will establish a hybrid regulatory framework on CSR information disclosure.

Besides, based on a study from the Chinese Academy of Social Science in 2011 on CSR reporting among listed companies in 2010, it appears that CSR-related reports are delivered in various ways. Regarding the presentation of the report, 99.1 per cent of the reports were delivered as separate documents. In terms of the degree of detail in the report: 38.2 per cent of the reports are less than 10 pages long; while 10.8 per cent of the reports are 31 to 50 pages long; and only 3.2 per cent of the reports are more than 90 pages long. Indeed, more lengthy reports do not necessarily mean more informative reports. However, variations in lengths of the reports will make the quality and scope of the disclosure differ dramatically. Moreover, the titles of the reports are also varied, they range from 'CSR Report' or 'Sustainability Report' to 'Corporate Citizenship Report' and 'Corporate Environmental Report'. These different titles may lead to differences in terms of the content of the reports. ${ }^{65}$ This survey revalidated the importance of primary arguments about combined regulatory documents in terms of the nature and scope of these materials, which must work together coherently with disclosure regulations regarding non-financial issues and social, environmental and governance performance. However, a distinct problem revealed by the survey was the irregular nature and different scope of corporate reports on CSR issues. What the Chinese regulatory framework needs is a mandatory requirement for public companies to produce reports on both financial and non-financial aspects of corporate behaviours and decisions with clear and enforceable scope for non-financial reports. In principle, the proposed legislation should adopt CSR elements in order to promote sustainability of the company and satisfy the corporate objectives set out in CCL 2006.

\section{Learning from legislative experiences of information disclosure on social and environmental issues from the UK}

The direct transplantation of foreign law, including laws on information disclosure requirements, always needs to ensure that the new system fits into the cultural, legal, historical and political environment of China. Corporate social and environmental disclosure has become an important component of efficient CSR implementation. If there are not enough incentives for companies to report on their CSR impact in a voluntary manner based on market forces, the local government can make it a legal requirement for companies to produce these reports through corporate law, stock-listing regulations, tax law, pension fund regulations or even separate compulsory disclosure laws, setting precise standards for corporate reporting including requirements for lists of metrics, formats for

64 M Huang, J Shi and Y Wang, 'The Effect of Mandatory CSR Disclosure on Information Asymmetry: Evidence from a Quasi-natural Experiment in China' paper presented at Asian Finance Association Conference 2013 <http://papers.ssrn.com/sol3/papers.cfm?abstract_id=2206877> 4-5.

65 Research Centre for Corporate Social Responsibility of the Chinese Academy of Social Science, General Overview of CSR Reporting in China <www.cass-csr.org/index.php?option=com content\&module $=30 \&$ sortid $=44 \&$ artid $=300>$. 
reports and the frequency of reporting. ${ }^{66}$ In order to make this legal system complete and enforceable, the information disclosed should be calculated, evaluated and studied by government agencies or independent third parties. Additionally, there should be stipulated mandatory sanctions for failures to report any of these compulsory data. ${ }^{67}$

Based on the data produced by the KPMG International Survey of Corporate Responsibility Reporting 2011 and 2013, ${ }^{68}$ more than 90 per cent of listed companies produce a corporate report and the average quality of reports of UK companies is scored at 76; that is better than France, Germany, Japan and the USA, while Chinese companies scored lower than all of these with a score of $39 .{ }^{69}$ The most distinctive achievement of the UK is its near unanimous adherence to corporate responsibility - 100 per cent in 2011 . From the side of the government, the UK Department for Business, Innovation and Skills consulted on improving the quality of narrative reporting by quoted companies in their annual reports, including a proposal for listed companies to disclose the proportion of women on their boards and in the company. This reputable CSR information disclosure record is, in the opinion of the author, in a way related to the mandatory requirements on strategic reporting in the Companies Act 2006. While there is a legal requirement on information disclosure, directors will voluntarily also consider producing reports on social, environmental and human rights issues. It will also make the directors consider preparing a CSR report, and affect the content of the directors' annual report. Companies may also choose to cross-refer to their CSR report from their directors' report and strategic report. ${ }^{70}$

UK company law has gone through a series of reforms since 1995 with the adoption of the legislative principle of the enlightened shareholder value principle (ESVP), ${ }^{71}$ involving elements of social responsibility and stakeholderism and including the legislative adoption within company law of information disclosure regarding non-financial issues. Corporate disclosure has long been regarded as an important way of enhancing corporate accountability and improving the transparency of corporate activities. In light of the growing awareness of long-term development and stakeholder considerations, there has been an increasing demand for corporations to produce reports detailing their commitment to social and environmental issues. A significant modification in the UK Companies Act 2006 was the introduction of the business review as the replacement of the operating financial review (OFR), ${ }^{72}$ in line with the minimum requirements of the EU Accounts Modernisation Directive 2003 which called for a company's annual report to include 'both financial and, where appropriate, non-financial key performance indicators relevant to the particular business, including information relating to environmental and employee matters

66 C Noronha, S Tou, M I Cynthia and J J Guan, 'Corporate Social Responsibility Reporting in China: An Overview and Comparison with Major Trends’ (2013) 20 Corporate Social Responsibility and Environmental Management 29, 30 .

67 Ibid

68 KPMG (n 31) and KPMG (n 28).

69 KPMG (31) 39.

70 Deloitte, The Strategic Report: A Practical Guide to the New Regulations (Deloitte 2013) <www.deloitte.com/assets/Dcom-UnitedKingdom/Local\%20Assets/Documents/Services/Audit/uk-auditthe-strategic-report-a-practical-guide-v.pdf $>9$.

71 For a comprehensive and detailed discussion on ESVP, see A Keay, The Enlightened Shareholder Value Principle and Corporate Governance (Routledge 2013).

72 The OFR requirement was amended on 21 March 2005 in Schedule 7ZA UK Companies Act 1985; see also Company Reform Bill ss 393-5. 
(when necessary)' ${ }^{73}$ The directive is regarded as the response to the introduction of the programme of sustainable business development from the European Commission, with a recommendation on environmental disclosures that led to the inclusion of a fair review of the business in the accounts. ${ }^{74}$

After the enforcement of s 417 of the UK Companies Act 2006, the directors' report in the form of a business review became the central narrative reporting document in the corporate disclosure regime. ${ }^{75}$ The government's intention was to use an enhanced directors' report, specifically the business review, to satisfy EU and investor requirements. The general idea is that the business review's requirements for directors 'will be less onerous on companies but still useful for investors and other stakeholders' ${ }^{76}$ The amendment places an obligation on the directors of public companies to include in their annual business review anything that might be a liability to the company's profits through danger to its reputation, such as contracts with stakeholders who could potentially expose the company to risk through social or environmental harm. ${ }^{77}$ The purpose of the business review is 'to inform members of the company and help them assess how the directors have performed their duty under section $172,{ }^{78}$ The obligations imposed on quoted companies are more onerous in comparison. Their business reviews must 'to the extent necessary for an understanding of the development, performance or position of the company's business' include 'the main trends and factors likely to affect the future development, performance and position of the company's business and information about environmental matters, the company's employees, [and] social and community issues'. ${ }^{79}$ If discretion is involved, directors will need to put 'good faith' as the criterion for making business decisions to promote the success of the company, using their power to decide whether or not to disclose information.

However, it is also argued that, in order to make the business review achieve the aim associated with directors' duties to promote the success of the company, it is important to offer more guidance to directors to avoid a box-ticking approach, especially in terms of the provision of a definition for non-financial key performance indicators. Furthermore, it is debatable whether the review will constitute a genuine account of the stewardship of all relationships in which the company is involved. On the positive side, as the second limb of the ESVP embedded in s 172 of the UK Companies Act 2006, the requirement for a business review to be prepared and published, pursuant to the requirements in the Companies Act 2006, can do a good enough job if companies embrace the idea underpinning the need for it. It provides legislative support for minimum information disclosure in company law statutes on environmental and social issues. The requirement is regarded as one of the main approaches to the legal enforcement of CSR-related corporate strategy. 80

73 Article 14 amending Article 46 of the Accounts Directive.

74 See European Commission, 'Towards Sustainability' (COM(92)(23)(5).

75 Aiyegbayo and Villers (n 45) 699.

76 A Reese, Operating and Financial Review and the Business Review (WSP Environmental December 2005).

77 D Arsalidou, 'The Withdrawal of the Operating and Financial Review in the Company Bill 2006: Progression or Regression?' (2007) 28 Company Lawyer 131, 134.

78 S $417(2)$ UK Companies Act 2006.

79 S 417(5) UK Companies Act 2006.

80 See V H Ho, 'Enlightened Shareholder Value: Corporate Governance beyond Shareholder-Stakeholder Divide' (2010) 36 Journal of Corporation Law 59; D K Millon, 'Enlightened Shareholder Value, Social Responsibility, and the Redefinition of Corporate Purpose without Law' in P Vasudev and S Watson (eds), Corporate Governance after the Financial Crisis (Edward Elgar 2012) 68. 
The Companies Act 2006 (Strategic Report and Directors' Report) Regulations 2013 amended the UK Companies Act 2006 regarding the issue of information disclosure. Similar to OFR and business review, writers of strategic reports will need to consider which CSR elements are material to the successful performance of the company and which are in line with the directors' duty 'to promote the success of the company'. These regulations came into force on 1 October 2013 and will take effect for financial years ending on or after 30 September 2013. Companies with a calendar year end therefore needed to include modified corporate reports when they published their 2013 reports in spring 2014. Section 417 of the Companies Act 2006 was repealed in the Companies Act 2006 (Strategic Report and Directors' Report) Regulations 2013. ${ }^{81}$ Instead of a 'business review', companies must now produce a 'strategic report' pursuant to the new sections 414A-D of the Companies Act 2006.

The nature and scope of the strategic report principally replicates the business review. However, there are also a few changes for quoted companies. Firstly, apart from environmental matters, company employees and social and community issues, ${ }^{82}$ quoted companies will also have to include, 'to the extent necessary for an understanding of the development, performance or position of their business', information about human rights issues, including information on any human rights policy and its effectiveness. ${ }^{83}$ Secondly, quoted companies will also have to include, with the purpose of enhancing the requirements on employees:
a breakdown showing, at the end of the financial year, (i) the number of persons of each sex who were directors of the quoted company, (ii) the number of persons of each sex who were senior managers of the quoted company and the undertakings consolidated in the quoted company's accounts, and (iii) the number of persons of each sex who were employees of the quoted company and its consolidated undertakings. ${ }^{84}$

Thirdly, taking the environmental issues one step further, 'disclosure concerning greenhouse gas emissions' was introduced into part 7 of the directors' report, where a quoted company is required to 'state the annual quantity of emissions in tonnes of carbon dioxide'. ${ }^{85}$ Another two terminologies were also introduced to consolidate the scope of strategic reports from quoted companies, namely 'company's strategy' and 'business model'. 86 These are terms that are repeatedly used in corporate governance codes when discussing annual reports, ${ }^{87}$ long-term corporate value ${ }^{88}$ and advice from audit committees. ${ }^{89}$ Therefore, this new requirement can be regarded as a bridge between the UK Companies Act 2006 and the UK Corporate Governance Code, making existing 'comply or explain' disclosures mandatory. In the author's opinion, the new strategic report has not substantially changed the requirements embedded in the business review. However, it is positive to see more detailed requirements regarding employees and environmental issues, as well as a recognition of human right issues and links with corporate governance codes and information disclosure for quoted companies.

81 S 5 UK Companies Act 2006 (Strategic Report and Directors' Report) Regulation 2013.

82 S 417(5) UK Companies Act 2006.

83 S 414C(7)(b) UK Companies Act 2006 (Strategic Report and Directors' Report) Regulation 2013.

84 Ibid s $414 \mathrm{C}(8)(\mathrm{c})$.

85 Ibid s 15(2).

86 Ibid s 414C(8)(a)(b).

87 S C1.1. UK Corporate Governance Code 2012.

88 Ibid s C1.2.

89 Ibid s C3.4. 
In China, mandatory information disclosure within the company law legislation will make the corporate objectives-related provision, Article 5 of CCL 2006, which requires companies to undertake social responsibility and observe business ethics, enforceable and effective. ${ }^{90}$ Although there has been an increasing trend for disclosure through empirical research, ${ }^{91}$ minimum requirements for listed companies within CCL will be helpful in promoting transparency through corporate information disclosure on social and environmental issues, in order to mitigate negative impacts, such as corporate scandals, and to promote and establish the centrally planned harmonious society. The legal requirements will also be of value to society more generally, either better to gauge the development of policy or to supplement the enforcement of policy by regulatory organisations. ${ }^{92}$ Moreover, if CSR information disclosure is becoming an increasingly accepted corporate strategy in practice, legal requirements within CCL will make such common commitments unified and standardised. Finding the most appropriate regulatory framework that is efficient, enforceable and fits into the national legal system and economic development stage seems much more sensible than arguing about the nature of CSR if it is truly voluntary. It is argued by Buhmann that legislation on normative CSR may constitute pre-formal law. ${ }^{93}$ The regulatory focuses on CSR, in a positive and progressive manner, will make corporations 'want to do what they should do'.94 The legal recognition of CSR will create institutional constraints on directors' discretions when making decisions and facilitate corporate goals towards interests of a wide community of stakeholders for the social, environmental and, most importantly, long-term corporate interests. ${ }^{95}$ Therefore, the mandatory requirement on CSR-related information disclosure can be regarded as a very effective initial step for establishing a systemic CSR legislative framework.

With the addition of supplementary enforcement measures, such as quantitative information requirements, corporate accounting standards and recruitment form reporting for annual reports, legislative experiences on the strategic report from the UK Companies Act 2006 are helpful for CCL legislation development. In detail, firstly, regarding the regulative objects, 'a quoted company' must include information about environmental matters, employees and social, community and human rights issues in its strategic report

90 See ss 172 and 414C UK Companies Act 2006; also in Sweden, Spain and Finland, state-owned companies are required to report on different aspects of their non-financial performance, e.g. Government Resolution of State Ownership Policy 2011 (Finland), Article 39 Spanish Sustainable Economy Law 2011, and Guidelines for External Reporting by State-owned Companies 2007; the German Reform Act on Accounting Regulations 2004 requires that companies examine and report on key financial and non-financial indicators that materially affect the development or performance of the company in their annual report; Article 225 French Grenelle II Act imposed a CSR-reporting and social and environmental information obligation for listed companies and other companies based on the number of employees and balance sheet total; furthermore, with the aim of motivating and inspiring Danish business to take an active position on CSR, the Danish Parliament (Folkertinget) passed a Bill in 2008 as an amendment to the Danish Financial Statement Act. As a result, approximately 1100 large businesses in Denmark are now legally required to include reports on three dimensions in their annual report, including CSR policies, how these policies are translated into actions and what the business has achieved as a result of working with CSR, and expectations for the future.

91 KPMG (n 31); see also C Marquis and C Qian, 'Corporate Social Responsibility Reporting in China: Symbol or Substance?’ (2014) 25 Organization Science 127.

92 M J Rhodes, 'Information Asymmetry and Socially Responsible Investment' (2010) 95 Journal of Business Ethics 145, 148.

93 K Buhmann, 'Corporate Social Responsibility: What Role for Law? Some Aspects of Law and CSR' (2004) 4 Corporate Governance 188, 192.

94 P Selznick, The Communitarian Persuasion (Woodrow Wilson Centre Press 2002) 102.

95 C Nakajima, 'The Importance of Legally Embedding Corporate Social Responsibility' (2011) 32 Company Lawyer 257, 258 
based on the Companies Act 2006.96 Similarly, in the proposed section on CSR-related information disclosure in CCL, the regulatory objective should apply to listed companies in China. This requirement makes information disclosure possible and logical with the possible link with the corporate governance code, and the CSR of these listed companies will have a bigger impact on stakeholders. These listed companies are likely to have instant and broader influence on both society and community since they have multi-stakeholder groups, which in turn will have a further effect on CSR information disclosure. Moreover, the listed companies always play an active role in social activities, and are closely followed by the public and regulated by the government with associated high political costs and attention. ${ }^{97}$ They are more likely to disclose information in detail in order to reduce political concerns and relieve political and supervisory pressure. ${ }^{98}$ Therefore, companies listed on the stock exchange should be a regulatory target for mandatory CSR disclosure, while corporation size should prompt companies to decrease social pressure by disclosing to the public with positive effects.

The content of the report in CCL should be consistent with the requirements in UK law on the scope of the reporting to include environmental, social, community and human rights issues. Basic concerns surrounding these issues will help corporations to establish a reputable corporate image, win understanding and support from local communities and other stakeholders through communications, and enhance the credibility of their reports. This legal requirement would partly solve the problem of the lack of a unified mandatory social responsibility information disclosure format, replacing the current inadequate qualitative and quantitative information that results in questionable reliability and poor comparability of CSR information between companies. ${ }^{99}$ The human rights element will support China's endorsement of the 'Guiding Principles on Business and Human Rights: Implementing the United Nations "Protect, Respect and Remedy" Framework', where business and human rights came together. ${ }^{100}$ The Ruggie Guiding Principles are grounded in a recognition of the state's existing obligations to respect, protect and fulfil human rights and fundamental freedoms, ${ }^{101}$ which have been regarded as the three pillars of the framework. The endorsement of the Ruggie Framework together with legislative experience of strategic reports will make the corporate responsibility to respect, protect and fulfil human rights desirable for this proposed legislative reform.

Furthermore, the term 'key performance indicators', defined as factors by reference to which the development, performance or position of the company's business can be measured effectively, ${ }^{102}$ should also be introduced into CCL in order to make information disclosure effective, relating to environmental and employee matters, as non-financial

96 S 414C(7)(b) UK Companies Act 2006 (Strategic Report and Directors' Report) Regulation 2013.

97 R Watt and J Zimmerman, 'Towards a Positive Theory of the Determination of Accounting Standards' (1978) 53 Accounting Review 112, 115-16.

98 S S Cowen, L B Ferreri and L D Parker, 'The Impact of Corporate Characteristics on Social Responsibility Disclosure: A Typology and Frequency-based Analysis’ (1987) 12 Accounting, Organizations and Society 111, 113-14.

99 Y Tang and D Chen, Analysis of Present Situation, Foundation and Content about Corporate Social Responsibility Information Disclosure in China' (2012) M\&D Forum 96, 98.

100 J Ruggie, 'Business and Human Rights: Together at Last: A Conversation with John Ruggie' (2011) 35 Fletcher Forum of World Affairs 117; for more discussion on China and the international human rights system, see S Sceats and S Breslin, 'China and the International Human Rights System' (Royal Institute of International Affairs 2012).

101 Guiding Principles (a), 'Guiding Principles on Business and Human Rights: Implementation of the United Nations "Protect, Respect and Remedy" Framework'.

102 See s 414C(4) UK Companies Act 2006 (Strategic Report and Directors’ Report) Regulation 2013. 
information disclosure targets. Despite criticism on offering more guidelines related to these indicators in UK law, this minimum requirement should be regarded as the precondition for a more mature legislative treatment of information disclosure within CCL. This requirement fits within the triple-bottom-line framework, which includes environmental issues (energy, water, waste and legal compliance), social issues (recruitment, employees' rights, health and safety, training and education, non-discrimination, child labour, bribery and community investment) and financial issues. ${ }^{103}$ Focusing on the last of these three factors, corporations will be able to achieve their operational targets and economic goals, which are regarded as the pre-conditions for disclosing their CSR information, because those corporations with poor performance are always unlikely to undertake CSR or engage in CSR information disclosure. ${ }^{104}$ In order to promote CSR in a systematic manner, an evolving CSR reporting system should be established with different levels of performance indicators. ${ }^{105}$ The transplant of legislative experience from the UK Companies Act 2006 will enable China to improve the breadth of disclosure to satisfy stakeholders' needs and simultaneously foster corporate values. The transplant will also help CCL to develop in line with international principles and other soft laws, such as corporate governance codes.

\section{The unique mandatory CSR information disclosure system in China}

Legislative experience on strategic reports from the UK Companies Act 2006 is transplantable for adopting a minimum standard at the national level to promote CSR and corporate transparency. However, path dependence theory attributes national differences in corporate law and corporate governance models to divergent historical and social underpinnings in different jurisdictions, and suggests that 'the lesson of history . . . is that while markets have always been there, they have always operated in the context of geography, religion, language, folk ways, families, armies, and government, never in a vacuum'. ${ }^{106}$ Path dependence, a comparatively new theory originating in the 1980s, suggests that an outcome or decision is shaped in specific and systematic ways by the historical path leading to it, as well as by other factors within the socio-economic context. ${ }^{107}$ While convergence theorists predict that countries, especially countries with weak legal systems, will adopt certain legal rules that have been demonstrably efficient in other jurisdictions, theorists who adhere to path dependence normally argue that divergence will still exist because legal rules are shaped by pre-existing political and social forces. ${ }^{108}$ As part of the domestic legal and financial framework, a corporate law system has significant sources of path dependence, which include historical accidents as well as economic and political

103 International Finance Corporations and Shanghai Stock Exchange, Sustainability Reporting Guidelines: Mapping and Gap Analyses for Shanghai Stock Exchange (2011) <www1.ifc.org/wps/wcm/connect/ 19231a804886585bb596f76a6515bb18/SSE_IFCReport\%2BEnglish.pdf?MOD=AJPERES\&CACHEID=1 9231a804886585bb596f76a6515bb18> 3-4; see also T F Slaper, 'The Triple Bottom Line: What Is It and How Does It Work?' (2011) 86 Indiana Business Review 4.

104 J L Campbell, 'Why Would Corporations Behave in a Socially Responsible Way? An Institutional Theory of Corporate Social Responsibility' (2007) 32 Academy of Management Review 946.

105 J Wang, S Qin and Y Cui, 'Problems and Prospects of CSR System Development in China' (2010) 5 International Journal of Business Management 128, 133.

106 K Moore and D Lewis, Foundations of Corporate Empire: Is History Repeating Itself (Financial Times/Prentice Hall 2000) 219.

107 O A Hathaway, 'The Course and Pattern of Legal Change in a Common Law System' (2001) Iowa Law Review 101, 103-04.

108 K Pistor, 'Patterns of Legal Changes: Shareholder and Creditor Rights in Transition Economies' EBRD Working Paper 49 (2000). 
particulars of the domestic system. ${ }^{109}$ The persistence of these sources significantly contributes to the stability of the domestic corporate governance system in any local socioeconomic environment.

Path dependence theory can be regarded as a theoretical base for the adoption of a mandatory information disclosure system with many unique characteristics shaping a particular nation's unique corporate governance model and transformation, corporate law development, enforcement process, shareholding structure, civil procedure law, stage of economic development, history, culture and traditions. It has been argued by Bebchuk and Roe that the initial ownership structure in a country will directly influence the subsequent development of its ownership structure and laws. ${ }^{110}$ Furthermore, these authors developed the theory to suggest that the interested parties possessing the power to influence ownership structure and corporate law will have both the incentive and the power to impede changes that might improve efficiency but are contrary to their private control interests. ${ }^{111}$

The enforcement of law and regulatory systems for corporate information disclosure will be different in China than it is elsewhere, due to the unique and historical social relationships between controlling shareholders and local government, and the guanxi between controlling shareholders and company directors. ${ }^{112}$ The uniqueness of the information disclosure system stems from the special relationship with the report's readers and the fact that China was the first Communist nation in the world to have a stock exchange, and since 1990 it has been the only socialist country to initiate the creation of a market-style modern enterprise system, achieved through a corporatisation and shareholding framework but without privatising its SOEs. ${ }^{113}$ China needs a unique system of its own, shaped by the 'socialist market economy with Chinese characteristics'. By extension, this is also the case for a putative and unique Chinese CSR information disclosure system.

\subsection{DeVELOPING REGULATIONS FROM MULTIPLE LEGISLATIVE SOURCES}

The Chinese Stock Regulatory Commission made CSR reporting a formal requirement for companies from the financial industry, companies listed on foreign exchanges and companies in the corporate governance composite index group on the Shanghai Stock Exchange and companies in the Shenzhen 100 composite stock index. However, no guidelines have been provided by the Chinese Stock Regulatory Commission on any details of the information that should be disclosed and directors have some discretion on information that should be reported. However, the impact of this legislation is limited by the legislative objective and lack of guidelines for enforcement.

According to the Constitution of the People's Republic of China 1982 and the Law on Legislation of the People's Republic of China 2000, statutory laws can be classified into two tiers at the national level and the local provincial level according to the hierarchy of their authority. ${ }^{114}$ Legislation may take the form of laws, regulations, rules, measures, decisions or resolutions, although law is the most commonly used type. Below the Constitution and

109 L Bebchuk and M J Roe, 'A Theory of Path Dependence in Corporate Governance and Ownership' (2000) 52 Stanford Law Review 127.

110 Ibid.

111 Ibid 132.

$112 \mathrm{~J}$ Zhao and S Wen, 'Gift Giving, Guanxi and Confucianism in a Harmonious Society: What Chinese Law could Learn from English Law on Aspects of Directors’ Duties’ (2013) 34 Company Lawyer 381.

113 See C Yao, Stock Market and Futures in the People's Republic of China (OUP 1998).

114 See Article 95 Constitution of the People's Republic of China 1982 and Article 2 Legislation of the People's Republic of China 2000. 
law are administrative regulations made and amended by the State Council. These legislative approaches all fit into the CSR information disclosure system, as a key part of corporate strategy for Chinese companies through gaining trust and credibility from the government and the public. It is believed that mandatory CSR information disclosure will assess the congruence between the social value implied by corporate activities and social norms. ${ }^{115}$ However, it is necessary to integrate an efficient and comprehensive CSR information system with a minimum standard from corporate law via the government legislative framework level and supplemented by regulations from stock exchange, province and city level. Therefore, a unique and hybrid CSR information disclosure regulatory framework, incorporating legislative elements from company law (as suggested in this article and informed by the legislative experience from the strategic report from the UK Companies Act 2006), as well as other regulatory instruments from the stock exchange, government authorities and agencies in other forms, will work for China to fit its unique corporate governance model. This hybrid CSR information disclosure framework should be directed by mandatory rules in CCL and supplemented by government legislation, regulations and guidelines from government authorities, agencies at different levels and stock exchanges.

Apart from guidelines at the provincial level, other government legislation should also put CSR information disclosure on the agenda to enhance a more efficient hybrid framework. For example, a problem that was revealed by the Study of Corporate Social Responsibility Reports in China 2012-2013 by SynTao is the low percentage of independent auditing of CSR reports (only 3 per cent). ${ }^{116}$ Critics argue that CSR reports without independent third-party inspection and supervision are no more than company brochures. ${ }^{117}$ Therefore, in order to enhance the effectiveness of mandatory CSR report proposals within CCL, it might be worth arguing the case for adopting a mandatory independent auditing process for CSR reporting in Chinese auditing law or in the Regulations for the Implementation of the Audit Law of the People's Republic of China. Independent auditing will work with intense monitoring from stakeholders and verification from public sources such as the Environmental Protection Bureau and the media.

As far as the detailed requirements and guidelines for drafting and implementation of CSR reports are concerned, 'G4 Sustainability Guidelines: Reporting Principles and Standard Disclosure' and 'G4 Sustainability Guidelines: Implementation Manual', ${ }^{118}$ both published by Global Reporting Initiative, are worth referencing to produce reports that meet international standards. The guidelines offer 'Reporting Principles, Standard Disclosures and an Implementation Manual for the preparation of sustainability reports by organizations, regardless of their size, sector or location'.119 'The Guidelines also offer an international reference for all those interested in the disclosure of governance approach and of the environmental, social and economic performance and impacts of organizations. ${ }^{120}$ Therefore, the guidelines will be applicable to listed companies in China in the preparation of their CSR reports on social, environmental and economic issues. Furthermore, the guidelines were drafted through a global multi-stakeholder process with the involvement of

115 J Wang, L Song and S Yao, 'The Determinants of Corporate Social Responsibility Disclosure: Evidence from China' (2013) 29 Journal of Applied Business Research 1, 1.

116 SynTao (n 29) 7.

117 Q Pang, 'Study: China's CSR Reports Need Improvement' Global Times (25 November 2010); available via <www.globaltimes.cn/content/596632.shtml>; see also D Kershaw, 'Waiting for Enron: The Unstable Equilibrium of Auditor Independence Regulation' (2006) 33 Journal of Law and Society 388.

118 Global Reporting Initiative, G4 Sustainability Guidelines: Reporting Principles and Standard Disclosure/Implementation Manual (2013) < www.globalreporting.org>.

119 Ibid 5.

120 Ibid. 
representatives from various stakeholders and gatekeepers, including auditors. These internally recognised guidelines are also consistent with the logic of mandatory CSR reporting in CCL, as discussed in section 3.

\subsection{APPLYING A TWO-WAY COMMUNICATION CSR REPORTING SYSTEM IN CHINA}

There is a range of methods to evaluate when seeking possible legislative protection for stakeholder groups, with relevant factors such as the introduction of provisions that mandate (or at least give legitimacy to) the relevant behaviour with specific enforcement measures. Despite the fact that companies are increasingly disclosing CSR information, it is questionable whether the current annual, standalone CSR reports on social and environmental factors can satisfy the increasing demand for corporate accountability. 121 The reporting system is still underdeveloped, and it is necessary to further enhance sustainability reporting and CSR reports by adopting a more systematic and standardised format in comparison with traditional economic reporting. ${ }^{122}$ Mandatory or voluntary reports on social and environmental issues are not normally exclusive options in current practice; in fact they are highly complementary. Disclosure practice by companies may be driven by the need to legitimise their corporate activities. It is for the government to decide the most appropriate approach for reporting, with different levels of minimum mandatory requirements based on different criteria, including business nature and the size or type of the corporation. ${ }^{123}$

It is argued that CSR-related communications between corporations and their stakeholders were carried out in the form of annual CSR reports, or via the presence of CSR information in financial reports. ${ }^{124}$ These reports transfer CSR-related information from the company to stakeholders, and are only issued and disclosed after the achievement of the CSR-related activities. ${ }^{125}$ The process of transferring the information is via a oneway communication route, which is predictable, insufficient and not always transparent enough regarding comments and timeliness to give stakeholders a good understanding of the corporation's CSR decisions and actions. It is suggested that two-way communication, via a system under which information can be transferred between the company and its stakeholders in a bidirectional manner, should be established to make the CSR information disclosure system more efficient. ${ }^{126}$ Under such a scheme, the 'informing' direction transmits CSR-related messages to stakeholders via reports and other media in order to involve them in the sustainable development of the company. This involvement will enable them to provide voluntary sustainable support for socially responsible corporate behaviours. On the other hand, the 'listening' direction will help the company to adapt to the needs of stakeholders by listening to their voices through questionnaires, surveys,

121 See C A Adams, 'The Ethical, Social and Environmental Reporting-Performance Portrayal Gap' (2004) 17 Accounting, Auditing and Accountability Journal 731; M J Milne and R Gray, 'Future Prospectus for Corporate Sustainability Report' in J Unerman, J Bebbington and B O’Dwyer (eds), Sustainability Accounting and Accountability (Routledge 2007) 184.

122 A R Belal and V Lubinin, 'Corporate Social Disclosure (CSD) in Russia' in S O Idowu and W L Filho (eds), Global Practice of Corporate Social Responsibility (Springer Verlag 2008).

123 KPMG, Unit for Corporate Governance in Africa, Global Reporting Initiative and United Nation Environment Programme, Carrots and Sticks: Promoting Transparency and Sustainability - An Update on Trends in Voluntary and Mandatory Approaches to Sustainability Reporting (KPMG 2010) 8.

124 M Liu, 'Corporate Social Responsible Actions and Consumer Respondents' (2006) 25 China Industry Economy 64.

$125 \mathrm{H}$ Chen and H Zhang, 'Two-way Communication Strategy on CSR Information in China' (2009) 5 Social Responsibility Journal 440, 441.

126 Ibid 442. 
consulting sessions and collective opinion pools. The company can then make changes to upgrade the sustainable support for its CSR activities, and these adjustments can be disseminated through reports on more efficient CSR-related developments and strategies. The importance of informing stakeholders about CSR-related information should be given an equal weight to communication with and support from stakeholders, in order to make the information more attractive, useful and dynamic. A two-way communication system will promote good relations between various stakeholders and corporations through 'identification', which makes stakeholders feel they are being integrated, acknowledging their individualised value and ultimately promoting the company. ${ }^{127}$

In the case of Chinese companies, it has been found that most CSR reports lack sufficient communication with various stakeholders of the company in order to adequately reflect their expectations. ${ }^{128}$ Zheng Wei, the senior project manager of CSR Asia, suggests that CSR reports should be linked closely to the interests of stakeholders. It is argued that 'for the case of Chinese listed companies, the earlier you learn your stakeholders' expectations, the more attractive and effective your CSR report is'.129 A positive and appropriate dialogue with stakeholders is key to justifying the reasonableness and competitiveness of CSR reports, accommodating the needs of the reader and keeping them interested. This positive reaction from internal and external environments to corporations' CSR communication strategies will ensure a positive strategic management policy, boosting CSR within corporations and enforcing enlightened corporate objectives by mapping stakeholder relationships and stakeholder coalitions, assessing the nature of each stakeholder's interests and power, constructing a matrix of stakeholders' priorities, creating a matrix of corporate responsibility towards stakeholders, and making the corporate objectives in CCL 2006 more enforceable. ${ }^{130}$ In this sense, a two-way disclosure system will propose a solid set of coherent principles and enforcement measures and processes, enhancing the integration of CSR initiatives as a key element of corporate culture and corporate value. Such a two-way strategy will help corporations to decide what to disclose and will encourage them to keep updating their information to make their CSR strategy fit their stakeholders' needs. To accommodate CSR projects that need a relatively long period of time for their implementation, a systematic two-way disclosure regime is key for the company in obtaining and disseminating updated social and environmental information. ${ }^{131}$ Therefore, the guidelines and regulatory principles from different levels in the combined regulatory framework should highlight the importance of stakeholder dialogue to promote a two-way communication system within the CSR reporting system.

\subsection{FORMS THROUGH WHICH CSR INFORMATION CAN BE DISCLOSED IN CHINA}

It is a practical issue to clarify the forms of CSR information disclosure that may be further required in other regulatory instruments from government agencies or authorities in order to enforce the mandatory requirement for strategic reports as stipulated within the UK Companies Act 2006. Regarding forms of CSR-related information disclosure, a few types

127 S Brammer and S Parvelin, 'Building a Good Reputation' (2004) 19 European Management Journal 704.

$128 \mathrm{Z} \mathrm{Li}$, 'Road to Transparency: The Current Situation, Tendency and Challenges of CSR Reports in China' in Social Resources Institute, Road to Transparency: The Current Situation, Tendency and Challenges of CSR Reports in China $<$ www.srichina.org $>4$.

129 W Zheng, 'Stakeholder Dialogue and Corporate Social Responsibility Communication' in Social Resources Institute (n 128) 6, 7-8.

130 J Zhao, 'Modernising Corporate Objective Debate towards a Hybrid Model' (2011) 62 Northern Ireland Legal Quarterly 361, 386.

$131 \mathrm{H}$ Chen, 'A Questionnaire Investigation on SRC in China' in Proceedings of the 2nd Euro-Asia Conference on Environment and CSR 12-13 October 2007, Bangkok, 56-60. 
of document have been examined, including annual reports, individualised reports, and non-report vehicles such as advertisements and company brochures. ${ }^{132}$ Of these public domain sources, there seems to be a consensus that annual reports are the most important and appropriate, ${ }^{133}$ being treated both as a stewardship tool ${ }^{134}$ and as an investment tool. ${ }^{135}$ CSR-related information has been disclosed in China through four means including scattered information disclosure through annual reports, individualised information disclosure through annual reports, individualised information disclosure separated from annual reports, and information disclosure through the public media and press releases. ${ }^{136}$ For scattered information disclosure, the information sources may be various documents such as corporate governance reports, business ethical reports, financial statements or their appendices, or directors' meeting reports where there is not a separate information disclosure report. However, there is a trend towards separate CSR reports with 99.1 per cent of companies choosing this option in a study from $2010 .{ }^{137}$

A scattered CSR information disclosure system always makes it troublesome and timeconsuming for investors and other stakeholders to find useful and necessary information. On the other hand, individualised CSR reports make the information clear, understandable, systematic and locatable. It is sensible for corporations to keep their reports reader-friendly and visually pleasing in order to attract investors, especially potential minority shareholders, and in order to build better stakeholder communication. It is important to avoid overly complicated social income statements, value-added sheets or balance sheets, but to make the information effectively and efficiently disclosed to various shareholders and stakeholders. Considering that listed companies are currently required to issue annual reports in any of the three, or even all of these three, designated national newspapers (China Securities Journal, Securities Times and Shanghai Securities Gazette Listed Firms), it might be beneficial and easier to make it mandatory for listed companies to disclose information on social, environmental and human rights issues within their annual reports. However, with the development of CSR, corporate governance and corporate law in China and collective efforts from corporate insiders and gatekeepers, a 'comprehensive report' framework, which includes three types of information for each disclosure CSR item (including the corporate vision and

132 D Campbell and A C Beck, 'Answering Allegations: The Use of the Corporate Website for Restorative Ethical and Social Disclosure' (2004) 13 Business Ethics: A European Review 100; see also D Zeghal and S A Ahmed, 'Comparison of Social Responsibility Information Disclosure Media Used by Canadian Firms' (1990) 3 Accounting, Auditing and Accountability Journal 38.

133 T A Lee and D P Tweedie, 'Accounting Information: An Investigation of Private Shareholder Usage' (1975) Accounting and Business Research 280; see also T A Lee and D P Tweedie, 'Accounting Information: An Investigation of Private Shareholder Understanding' (1975) Accounting and Business Research 280; E Mirfazali, 'Corporate Social Responsibility Information Disclosure by Annual Reports of Public Companies Listed at Indonesia Stock Exchange' (2008) 1 International Journal of Islamic and Middle Eastern Finance and Management 275; Szabo (n 15); S Arvidsson, 'Disclosure of Non-financial Information in the Annual Report' (2011) 12 Journal of Intellectual Capital 277; A Amran, S P Lee and S Selvaraj, 'The Influence of Governance Structure and Strategic Corporate Social Responsibility Toward Sustainability Reporting Quality' (2013) Business Strategy and the Environment <www.researchgate.net/publication/261565149_ Amran_A._Lee_S._P._and_S.Susela_Devi_\%282013\%29_The_Influence_of_Governance_Structure_and_St rategic_Corporate_Social_Responsibility_Toward_Sustainability_Reporting_Quality._Bus._Strat._Env>.

134 Caparo Industries plc v Dickman [1990] 2 AC 605 HL, per Lord Oliver of Aylmerton, 630-1.

135 PricewaterhouseCooper, Corporate Reporting: A Time for Reflection: A Survey of the Fortune Global 500 Companies' Narrative Reporting (PricewaterhouseCooper 2007) 6; see also Aiyegbayo and Villiers (n 45) 700.

136 Y Li and Y Liu, Bluebook of Corporate Social Responsibility in China 2011 (People's Publishing House 2011) 346.

137 Chinese Academy of Social Science, General Overview of CSR Reports in China (2010); see also Z Li, Research on Corporate Social Responsibility Information Disclosure (Qiye Shebui Zeren Xinxi Pilu Yanjiu) (Economic Science Press 2008) 143. 
goals, management approaches and performance indicators), ${ }^{138}$ seems workable in China. This is a framework that allows two important aspects of accountability, namely completeness and comprehensiveness, to be easily, directly and simultaneously assessed. ${ }^{139}$

The content of this comprehensive reporting system should be consistent with the one required by the strategic report, including environmental, employee, social, community and human rights issues. This also fits in with the empirical research carried out by Wang, Song and Yao on all A-share companies listed on the Shanghai Stock Exchange on the contents of their CSR reports including: environmental issues (such as pollution control, environmental conservation, natural resource conservation and energy-saving/emission reduction) and social issues (such as production quality and safety, customer services, consumer rights, philanthropic giving, public welfare undertaking and community involvement). The scope of the employee information may be interpreted broadly and refer to issues such as 'health and safety, human rights, schooling, education and career perspectives'. ${ }^{140}$ The content should be expanded to include human rights issues, especially after China's endorsement of the 'UN Guidelines on Business and Human Rights', in which business and human rights finally came together. ${ }^{141}$ In the 'General Principles' section the Ruggie Guiding Principles are grounded in a recognition of the state's existing obligations to respect, protect and fulfil human rights and fundamental freedoms, ${ }^{142}$ which have been regarded as the three pillars of the Ruggie Framework. The endorsement of the Ruggie Framework by the United Nations Human Rights Council on 16 June 2011, after years of struggle to develop corporate standards, made the corporate world's responsibility for human rights clear and is the foundation for this policy framework. The inclusion of human rights issues within the mandatory information disclosure requirement within the CCL is a golden opportunity for China and Chinese companies to promote their corporate image and human rights record.

\subsection{GOVERNMENT INTERFERENCE AND INFORMATION DISCLOSURE}

In the liberal political economy proposed by Adam Smith in his milestone work Wealth of Nations, ${ }^{143}$ the government monitors and enforces the regulatory environment in which companies compete for profit, but should not directly be involved in a company's decisions and transactions. Since that time, many reasons have been advanced arguing that state control over commercial transactions will lead to the failure of the business organisation. It is argued that, based on the efficiency of the corporate form, direct involvement of state officials will impose on companies multiple political interests which will dilute projectmaking motives when social objectives collide with shareholders' wealth maximisation. It is also argued that informational asymmetry and uncertainty will constrain the effectiveness of coordination and interference from government. The willingness of governments in sharing the risk might weaken motives of companies in making more profit and lead to soft budget constraints with negative effects on a firm's efficiency. However, the effectiveness and necessity of government interference in business organisations have been questioned

138 L Bouten, P Everaet, L V Liedekerke, L D Moor and J Christiaens, 'Corporate Social Responsibility Reporting: A Comprehensive Picture' (2011) 35 Accounting Forum 187.

139 Ibid 202.

140 T Lambooy and N van Vliey, 'Transparency on Corporate Social Responsibility in Annual Reports' (2008) 5 European Company Law 127, 128.

141 Ruggie (n 100); for more discussions on China and the international human rights system, see Sceats and Breslin (n 100).

142 Guiding Principles (a) (n 101)

143 A Smith, An Inquiry into the Nature and Causes of the Wealth of Nations, E Cannan (ed) (University of Chicago Press 1776). 
and discussed in various dimensions, especially after the financial crisis of 2008. Instead of having a direct role in facilitating and shaping dynamic growth, the state's ability to create and maintain a supportive growth climate is key for emerging markets to achieve economic miracles. ${ }^{144}$

In countries with emerging markets such as China, the incentives for and the quality of government officials and regulators are key determinants of corporate behaviour. ${ }^{145}$ Groups who have controlling powers over corporate resources always have political power and can affect the level of investor protection, mostly in an unfair manner. For example, controlling shareholders prefer legislation and rules that will put minority shareholders in a disadvantaged position. In the case of China, half of the listed companies are controlled by SOEs which account for more than half of output and employment. This reaffirms a major concern of corporate governance in listed companies in emerging economies, namely controlling-shareholder expropriation or principal-principal, where controlling shareholders pursue their self-interests at the expense of corporate performance and the interests of minority shareholders. ${ }^{146}$ SOEs play an important role in the Chinese economy to achieve the dual goals of shareholder profit maximisation and promotion of national interests.

As with the transformation of corporate governance and SOEs, so the development of CSR in China has to be achieved by informing the public and raising awareness of CSRrelated issues. ${ }^{147}$ CSR activities in China always include more involvement from government than similar initiatives in Western countries, where CSR strategies are driven by private sectors or non-governmental organisations. ${ }^{148}$ In China, the government plays a triple role in the enforcement of the law, promoting CSR as a regulator, a supervisor and a promoter. ${ }^{149}$ The 'Guidelines to the State-Owned Enterprises Directly under the Central Government on Fulfilling Corporate Social Responsibilities’ were effectively introduced by SASAC to promote socially responsible SOEs. The State Council publicly demonstrated its support for CSR by enacting and disseminating the 2008 SASAC Guideline. The introduction of this guideline is a strong indication that CSR has been centrally and politically authorised and accepted by the Chinese government and companies should implement their CSR policies to satisfy the trend. It is suggested that SOEs should establish a CSR information-releasing system, 'providing updates and regulator information about CSR performance and sustainable development, plans and measures in carrying out CSR'. ${ }^{150}$ This advice for SOEs can be regarded as an initial attempt at building a CSR information-releasing system: a unique system that can be developed to enable all listed companies to adopt policies to make CSR measureable and embedded within corporate strategic management policy. This guideline does not provide explicit or detailed

144 G Bertucci and A Alberti, 'Globalization and the Role of the State: Challenges and Perspectives' paper presented at United Nations World Public Sector Report 2001 on 'Globalization and the State'.

145 M Ararat and G Dallas, 'Corporate Governance in Emerging Markets: Why it Matters to Investors - and What They Can Do about It' (2011) Private Sector Opinion 1, 6.

146 Y Su, D Xu and P H Phan, 'Principal-principal conflict in the Governance of the Chinese Public Corporation' (2007) 4 Management and Organization Review 17; see also M N Young, M W Peng, G D Bruton and D Jiang, 'Corporate Governance in Emerging Economies: A Review of the Principal-Principal Perspective' (2008) Journal of Management Studies 196.

147 Knowledge Wharton, 'Corporate Social Responsibility in China: One Great Leap Forward, Many More Still Ahead' (University of Pennsylvania 2009).

148 L W Lin, ‘Corporate Social Responsibility in China: Window Dressing or Structural Change?’ (2010) 28 Berkeley Journal of International Law 64, 91.

$149 \mathrm{~J}$ Zhao, 'The Harmonious Society, Corporate Social Responsibility and Legal Responses to Ethical Norms in Chinese Company Law' (2012) 12 Journal of Corporate Law Studies 163, 199.

150 See State-owned Assets Supervision and Administration Commission, 'Guidelines to the State-Owned Enterprises Directly under the Central Government on Fulfilling Corporate Social Responsibilities', s 18. 
instructions on how to establish this information system. However, the adoption of strategic reporting from the UK Companies Act 2006 in the next CCL will be a very good start for this system. In this way, government interference will enable strategic reporting requirements to be enforced more effectively with the support of the SASAC guideline.

\section{Conclusion}

It is almost impossible to maximise companies' value and financial performance if they are not socially responsible and if they do not share their CSR information with the public. ${ }^{151}$ Furthermore, there is no point in companies investing in CSR activities without disclosing information of such activities in order to maximise their reputation. ${ }^{152}$ CSR-related information disclosure in annual reports will address public and legislative concerns and project an image of companies' social awareness. ${ }^{153}$ It is the KPMG view that the debate on whether corporations should publish a corporate responsibility report is over and listed companies that still do not do this 'should ask themselves whether it benefits them to continue swimming against the tide or whether it puts them at risk'. ${ }^{154}$ The question now that listed companies should ask themselves should be about the quality and content of their corporate responsibility reporting and the most efficient way to reach and communicate with the most relevant audience to achieve multiple stakeholder engagements. The author agrees with Professor Freeman's opinion on the future of CSR and the worthy goal of superseding CSR with a consideration that the roles of responsibility, sustainability and ethics are at least as important as the completion of projects. ${ }^{155}$

It is argued in this article that mandatory rules will help to produce narrative disclosures of a higher quality, which will lead to an increase in the amount of disclosure and reduce variability by an absolute amount attributable to the size of the company. The mandatory standards and rules, as well as voluntary guidelines, are key to achieving uniformity in CSR reporting, being reactive to environmental and social factors. This legitimate action could be regarded as evidence of an assessment of the company's corporate citizenship and as responses to social contracts, where corporations agree to perform various socially desirable actions in return for approval of their corporate citizenship as a reward for their ultimate survival. The legitimacy of their actions via disclosure will make corporations justify their continued existence.

It is clear that the system under which China could practise CSR information disclosure is a unique one within a unique corporate governance model and at a distinct stage of economic development with a shareholding structure and stakeholder groups like no

151 M L Pava and J Krausz, 'The Association between Corporate Social Responsibility and Financial Performance: The Paradox of Social Cost' (1996) 15 Journal of Business Ethics 321.

152 J Hasseldine, A I Salama and J S Toms, 'Quantity Versus Quality: The Impact of Environmental Disclosures on the Reputations of UK plcs' (2005) 37 British Accounting Review 231.

153 D M Patten, 'Intra-industry Environmental Disclosures in Response to the Alaskan Oil Spill: A Note on Legitimacy Theory' (1992) 17 Accounting, Organization and Society 471.

154 KPMG (n 31) 10.

155 Speech of Professor Edward Freeman at the Fifth International Conference on Corporate Social Responsibility: The Future of CSR, October 2012; based on the note of the author; see also E Freeman and A Moutchnik, Stakeholder Management and CSR: Questions and Answers (2013) Umwelt Wirtschafts Forum $<$ http://link.springer.com/article/10.1007\%2Fs00550-013-0266-3\#>. 
others. ${ }^{156}$ With the development of the Chinese economy, company law and corporate governance, the CSR information disclosure will not stay the same. However, the strategic reporting legislative experience from the UK seems appropriate and transplantable to promote CSR in China through corporate law legitimation. Similar to other transplantable legislative experiences from Western corporate law, for example, stock market rules and a corporate governance code, the local meaning and enforcement of these transplantations is inevitably different due to the dominance of the state in listed companies, as both shareholder and regulator. ${ }^{157}$ In the light of rapid Chinese economic development, social problems caused by profit-driven corporate decisions are hindering sustainability in China. Radical restructuring and privatisation in an atmosphere of irresponsible corporate behaviour has brought severe social instability and a wide range of stakeholder reactions. ${ }^{158}$ The enforcement of the law related to CSR in promoting stakeholders' interests depends heavily on political interference, public awareness, business disclosure of social and environmental issues, and the improvement and support of a sound legal system in China. The transplanted mandatory strategic reporting requirement in the next CCL, combined with additional regulatory documents and guidelines from local government, stock exchanges and government agencies, seems to comprise an efficient way to maintain a good balance and persuade companies to disclose their non-financial information. Furthermore, it is more efficient for CSR-related information to be mandated within the already existing framework of financial and non-financial information disclosure to fit into the philosophy of the business case of CSR. ${ }^{159}$ The rationales supporting the business community should engage and pursue CSR policies, activities and practices from a primarily corporate economic/financial perspective rewarded by the market, but also make CSR disclosure within the existing framework convincing and effective. ${ }^{160}$ The business case of CSR allows companies to benefit from CSR opportunities and enables them to enhance their competitiveness by multi-stakeholder engagement and communication, while mandatory CSR information disclosure within financial reports can be regarded as an effective means of acknowledging the interrelated nature of CSR and the financial performance of companies. ${ }^{161}$

Despite the positive trend towards increasing and better quality CSR reporting from Chinese companies, with associated progress towards a more comprehensive and competitive reporting system, this article recommends the adoption of the comprehensive report framework to facilitate the completeness and comprehensiveness of reports and improve corporate accountability towards the readers of the reports as well as shareholders who are potentially willing to invest. This promotion of comprehensive reporting is subject to the active participation of gatekeepers, such as accountants and auditors, to ensure the

156 For the unique corporate governance model in China, see O K Tam, 'Ethical Issues in the Evolution of Corporate Governance in China' (2002) Journal of Business Ethics 303; J Zhao and S Wen, 'Promoting Stakeholders' Interests in the Unique Chinese Corporate Governance Model: More Socially Responsible Corporations?' (2010) International Company and Commercial Law Review 373, 377-8; M Yan, 'Obstacles in China’s Corporate Governance’ (2011) Company Lawyer 311.

157 R Tomasic, 'Corporate Governance in Chinese-listed Companies Going Global' (2014) 2 Chinese Journal of Comparative Law 155, 155.

158 L Zu, Corporate Social Responsibility, Corporate Restructuring and Firm's Performance (Springer-Verlag 2009$) 301$.

159 See M Weber, 'The Business Case for Corporate Social Responsibility: A Company-Level' (2008) 26 European Management Journal 247.

160 A B Carroll and K M Shabana, 'The Business Case for Corporate Social Responsibility: A Review of Concepts, Research and Practice' (2010) International Journal of Management Review 85.

161 M L Barnett, 'Stakeholder Influence Capacity and the Variability of Financial Returns to Corporate Social Responsibility' (2007) 32 Academy of Management Review 794, 795. 
reports are comprehensible, competitive, complete and independent. Government plays a particularly important role in CSR reporting, not only for SOEs, which are directly controlled by central government, but also for their suppliers and customers. It is clear that inefficiency in the enforcement of CSR-related laws is a collective problem, with causes ranging from a poor information disclosure system, a record of disrespect for human rights and unregulated political power, to a high degree of political interference in the law, corporate governance and CSR. ${ }^{162}$

162 For more discussions on political interference and CSR, see P A Gourevitch and J Shinn, Political Power and Corporate Control: The New Global Politics of Corporate Governance (Princeton University Press 2007) chs 4 and 6; W Li and R Zhang, 'Corporate Social Responsibility, Ownership Structure, and Political Interference: Evidence from China' (2010) 96 Journal of Business Ethics 631; Y L Cheung, W Tan and Z Zhang, 'Does Corporate Social Responsibility Matter in Asian Emerging Markets' (2010) 92 Journal of Business Ethics 401; H Li, L Meng, Q Wang and L Zhou, 'Political Connections, Financing and Firm Performance: Evidence from Chinese Private Firms' (2008) 87 Journal of Development Economics 283. 
